\title{
DOCE AÑOS DE CONSEJO ECONÓMICO Y SOCIAL ESPAÑOL: ALGUNOS PROBLEMAS PENDIENTES
}

AURORA GUTIÉRREZ NOGUEROLES

Profesora de Derecho Constitucional 


\section{SUMARIO}

1. INTRODUCCIÓN. 2. LA FUNDAMENTACIÓN CONSTITUCIONAL DEL CES. 2.1. El artículo 131.2 CE: los argumentos en contra. 2.2. El artículo 131.2 CE: los argumentos a favor. 3. EL PROBLEMA DE LA DELIMITACIÓN CONCEPTUAL ENTRE DICTAMEN E INFORME. 3. 1. El planteamiento teórico del problema. 3.2. Planteamiento del problema en la práctica del CES. 4. LA DETERMINACIÓN DEL ÁMBITO OBJETIVO DEL DICTAMEN. 5. LA POSIBLE PERTURBACIÓN DE LA AUTONOMÍA DEL CES. 5.1. El riesgo de colisión entre la potestad reglamentaria del Gobierno y la del CES. 5.2. La "conexión gubernamental" del Presidente del CES. 5.3. Posibles limitaciones a la actuación individual de los Consejeros. 


\title{
DOCE AÑOS DE CONSEJO ECONÓMICO Y SOCIAL ESPAÑOL: ALGUNOS PROBLEMAS PENDIENTES
}

\author{
POR \\ AURORA GUTIÉRREZ NOGUEROLES \\ Profesora de Derecho Constitucional
}

\section{INTRODUCCIÓN}

Una de las preocupaciones más emblemáticas del denominado "Estado social y democrático de Derecho» es, sin duda, la de incentivar la participación de la sociedad civil en la toma de decisiones públicas, particularmente en las de carácter normativo. La última razón de ser de tan democrática preocupación no es otra que la de garantizar al Estado social frente a la burocratización y la tecnocracia1, a las que éste parece tender indefectiblemente. En definitiva, como afirma A. TORRES DEL MORAL, "en la igualdad y en la participación se aúnan el Estado social de Derecho y el Estado democrático de Derecho»². Por lo que hace a la participación, la Constitución española de 1978 resulta, sin duda, paradigmática desde el mismo momento en que, median-

1 En este sentido, Torres del Moral, A., Principios de Derecho Constitucional español, Servicio de Publicaciones de la Facultad de Derecho, Universidad Complutense, Madrid, 1998, pág. 50.

2 TorRes del Moral, Principios..., op. cit., pág. 51. 
te la solemne declaración contenida en el primero de sus artículos, se constituye como tal Estado social y democrático y, en lógica consecuencia de esa declaración, va incluyendo a lo largo de su articulado diversas manifestaciones del principio participativo ${ }^{3}$, que queda condensadamente enunciado en la precisa obligación que el artículo 9.2 CE4 impone a los poderes públicos de ufacilitar la participación de todos los ciudadanos en la vida política, económica, cultural y social».

Ahora bien, junto a esta consecuencia natural de índole sustantiva, la inclusión de la cláusula del Estado social (y democrático) en nuestra norma suprema puede originar también, como acertadamente afirma M. ARAGÓN, ciertos efectos de carácter estructural u organizativo, que, si bien no derivan de un modo necesario de dicha cláusula, sí encuentran en ella el básico estímulo para su producción ${ }^{5}$. Tal sería el caso de la creación de institutos u órganos consultivos que, integrados por representantes de los diversos grupos de intereses operantes en la sociedad civil, participan - de forma limitada, pero digna - en el proceso de adopción de determinadas decisiones públicas por los órganos estatales de poder político. Dentro del amplio elenco de modelos que responden a este planteamiento, destaca especialmente el representado por esas instituciones que suelen ser conocidas como "Consejos Económicos y Sociales" y que fundamentalmente

3 Sobre la incidencia del principio de participación en nuestro texto constitucional, vid. el fundamental trabajo de SÁNCHEZ MORÓN, M., «El principio de participación en la Constitución española», en RAP núm. 89 (1979); también, SÁNCHEZ BLANCO, A., "La participación como coadyuvante del Estado social y democrático de Derecho", en RAP núm. 119 (mayo-agosto, 1989); y RAMíREz, M., "Participación y pluralismo en la Constitución de 1978", en Estudios sobre la Constitución española de 1978, Edit. Pórtico, Zaragoza, 1979.

4 Este artículo - en opinión de TORRES DEL MORAL - "reúne en sí la doble idea del Estado social y del Estado democrático conjugando la libertad con la igualdad; el individuo con el grupo social; la participación económica, social y cultural con la participación política. Y todo ello como tarea de los poderes públicos". Cfr. Torres del Moral, Principios..., op. cit., pág. 51.

5 Vid. Aragón ReYes, M., "El Consejo Económico y Social de la Comunidad de Madrid", en El Derecho Público de la Comunidad de Madrid. Comentarios al XX Aniversario del Estatuto de Autonomía (dir. E. Álvarez ConDE), Edit. Centro de Estudios Ramón Areces, Madrid, 2003, pág. 607. En opinión de este autor, "el del Estado social es un principio básicamente material, del que no cabe derivar exigencias organizativas sustanciales, sino cumplimiento de fines", pero ello no es óbice para que pueda también tener una cierta relevancia desde el punto de vista estructural, ya que "faculta o fundamenta - que no exactamente impone- el establecimiento de instituciones de participación, en la actividad pública, de las organizaciones sociales y no sólo de las organizaciones politicas". 
se encargan, dentro de cada uno de los distintos niveles territoriales de poder político, de dictaminar el contenido de los textos normativos de carácter socio-económico cuando aún se hallan en fase de elaboración, es decir, antes de que pasen a ser debatidos y, en su caso, aprobados por las correspondientes Cámaras legislativas. El fin principal de esta función consultiva viene constituido por la defensa de los particulares intereses de los grupos sociales integrantes de dichos Consejos, toda vez que tales intereses pueden verse afectados por la regulación contenida en la norma objeto de dictamen. Se trata, pues, de acomodar, en la medida de lo posible, el "interés general», inspirador de la norma jurídica, a los intereses parciales o sectoriales de los grupos sociales que pueden resultar (o, de hecho, resultan) afectados por ella.

Tras la promulgación de la Constitución de 1978, en España se ha venido desarrollando - como se sabe - un gradual proceso de implantación de este tipo de institutos consultivos, que, tras el inicial impulso que le proporcionaron las autonomías territoriales ${ }^{6}$, ha tenido su culminación en la creación de un organismo consultivo estatal, el Consejo Económico y Social español (en adelante, CES), que nació a la vida institucional hace ahora doce años, por mandato de la Ley 21/1991, de 17 de junio.

6 En España, el fenómeno histórico de implantación de este tipo de instituciones tuvo su inicio en el ámbito autonómico, siendo sus primeras manifestaciones los Consejos de Relaciones Laborales del País Vasco (Ley vasca 9/1981, de 30 de septiembre), de Andalucía (Ley andaluza de 27 de junio de 1983), de Castilla-La Mancha (Decreto autonómico de 5 de julio de 1983), de Madrid (Decreto autonómico 3/1984, de 15 de enero) y de Galicia (Ley gallega 7/1988, de 12 de julio), así como los Consejos Económicos y Sociales del País Vasco (Ley vasca 4/1984, de 15 de noviembre), de Navarra (Decreto Foral 105/1987, de 20 de abril), de Asturias (Ley asturiana 10/1988, de 31 de diciembre), de La Rioja (Ley riojana $3 / 1989$, de 23 de junio), de Canarias (Ley canaria 8/1990, de 14 de mayo), de Castilla y León (Ley castellano-leonesa 13/1990, de 28 de noviembre), de Aragón (Ley aragonesa 9/1990, de 9 de noviembre), de Madrid (Ley madrileña 6/1991, de 4 de abril) y de Extremadura (Ley extremeña 3/1991, de 25 de abril). Esta iniciativa institucionalizadora de las Comunidades Autónomas puede quizás explicarse como un fiel reflejo del importante grado en que ha resultado afectada la clásica función consultiva estatal por la consolidación del denominado doctrinalmente "Estado de las Autonomías". En este sentido, aunque en exclusiva referencia a la función consultiva del Consejo de Estado, BLANCo VALDÉS, R. L., "Algunas reflexiones sobre el proceso de descentralización de la función consultiva del Estado, sobre su evolución y sus problemas", en Anuario de Derecho Constitucional y Parlamentario núm. 10 (1998), Asamblea Regional de Murcia y Universidad de Murcia, pág. 249. 
Con arreglo a esta Ley y a su normativa de desarrollo (el Reglamento de Organización y Funcionamiento (nterno ${ }^{7}$ ), el Consejo, integrado por 61 miembros $^{8}$, se configura como un ente de Derecho Público, con personalidad jurídica propia y adscrito al Ministerio de Trabajo y Seguridad Social (hoy, Ministerio de Trabajo y de Asuntos Sociales), siéndole asignadas funciones consultivas en materia socio-económica y laboral. Se integra, pues, tanto en la llamada "Administración institucional" (si bien al margen de la categoría de "organismos públicos" a que se refiere el artículo 41 de la Ley 6/1997, de Organización y Funcionamiento de la Administración General del Estado ${ }^{9}$ ), como en la Administración consultiva, toda vez que desempeña funciones de este carácter para el Gobierno en su conjunto o para alguno de sus Ministros. En cuanto que Administración institucional, goza de plena autonomia orgánica y funcional para el cumplimiento de sus fines, si bien con las limitaciones a que más adelante tendremos ocasión de referirnos. Se trata, pues, según lo califica R. PARADA, de un «ente especializado con autonomía real», esto es, de una más de las diversas

7 Este Reglamento fue aprobado por Acuerdo del Pleno del CES de 25 de febrero de 1993, siendo modificado posteriormente en cuatro de sus preceptos por Acuerdos del Pleno de 23/03/1994, de 21/09/1994 y de 21/06/1995. Además de ello, su articulado se ha visto ampliado por el Acuerdo del Pleno de 19/01/1994, que ha incorporado un nuevo artículo (el número 49), relativo al procedimiento de urgencia para la emisión de dictámenes.

8 De esta cifra, cincuenta y cuatro Consejeros actúan en representación de las diversas organizaciones sociales llamadas a integrar el Consejo y seis son expertos nombrados por el Gobierno. A todos ellos se suma el Presidente, también de designación gubernamental (a propuesta conjunta de los Ministros de Trabajo y de Economia).

9 Esta Ley, que tiene como uno de sus principales objetivos el de uracionalizar y actualizar la normativa dedicada a la tradicionalmente denominada Administración Institucional del Estado" (según afirma su Exposición de Motivos), se centra en la regulación detallada de la categoria de los "organismos públicos», a los que subdivide en dos tipos diferentes (los "organismos autónomos" y las "entidades públicas empresariales»), limitándose a destinar algunas de sus disposiciones adicionales a los demás entes que, aun siendo integrantes de dicha Administración, no pueden ser calificados legalmente como "organismos públicos" por no ejercer ninguna de las actividades que, según los artículos 45.1 y 53.1 LOFAGE, motivan tal calificación. Entre este conjunto de entes públicos "atípicos" o "apátridas" (según los denomina R. PARADA) que conforman, frente a la homogeneidad de la categoría legal de "organismos públicos", un heterogéneo "cajón de sastre", se encuentra, por supuesto, el CES, para cuya regulación remite la D.A. $10^{a}$ de la LOFAGE a su normativa específica. Vid. al respecto, PARADA VÁzouez, R., Derecho Administrativo (Organización y empleo público), Edit. Marcial Pons, Madrid, 1998, pág. 258. 
organizaciones encuadradas en la Administración institucional del Estado, que -en palabras del mismo autor- «han sido potenciadas por la Constitución de 1978 y encuentran en ella un principio de justificación, bien en preceptos expresos que la imponen para determinados servicios públicos, [...] bien en la invocación del control parlamentario o del principio de participación ciudadana, que la Constitución también consagra» ${ }^{10}$. Es en esta última referencia donde, lógicamente, cabría ubicar al CES.

Desde su constitución en 1991, la actividad consultiva del Consejo ha sido ciertamente apreciable, tanto dictaminando anteproyectos de leyes de muy relevante repercusión en el campo socio-económico, como emitiendo informes o estudios para el análisis de determinados problemas que lastraban el correcto funcionamiento de la sociedad española, o incluso elaborando cada año la memoria sobre la situación socio-económica y laboral española, siendo este último cometido el que, por su gran repercusión en los medios de comunicación social, quizás haya contribuido, en mayor medida que los demás, al conocimiento de la institución por la ciudadanía. Debe destacarse, pues, que su actividad cotidiana se ha inscrito siempre dentro de un contexto caracterizado por el normal funcionamiento de las instituciones estatales, según ha sido previsto y garantizado por nuestra norma suprema. Pero ello no es óbice para que podamos afirmar que subsisten, desde la creación del CES, determinados problema de índole jurídica - unos más próximos a lo estrictamente teórico y otros de mayor afinidad a la praxis-, que se hallan aún hoy pendientes de resolver. No es el menor de ellos, por cierto, el de su encaje constitucional, indudable objeto de controversia doctrinal, pero que, en tanto se considere al artículo $131.2 \mathrm{CE}$ como directo fundamento de la creación del Consejo (y tal es la opinión de quien esto escribe), sirve de principal justificante de la inclusión de este artículo en un número monográfico de la Revista destinado a conmemorar los veinticinco años de la Constitución vigente. De ahí que, por un mínimo de coherencia, debamos comenzar analizando esta capital cuestión de su ubicación constitucional, para continuar, de inmediato, con los restantes problemas detectados, que son los siguientes: la delimitación conceptual entre el dictamen y el informe; la determinación del ámbito objetivo de los dictámenes preceptivos; y la posible perturbación de la autonomía del CES (que, a su vez, cabe desglosar en los tres problemas a que más adelante nos referiremos).

10 Parada Vázouez, Derecho..., op. cit., págs. 207-208. 


\section{LA FUNDAMENTACIÓN CONSTITUCIONAL DEL CES}

El primer problema básico con que se encuentra el CES español es el de su fundamento constitucional, problema cuya resolución ha generado, ciertamente, una encendida polémica doctrinal desde el mismo momento en que el Consejo nació a la vida institucional española. En este sentido, podemos decir que la polémica surge básicamente al tratar de responder a una elemental pregunta sobre el CES: ¿se trata éste del innominado Consejo previsto en el artículo $131.2^{11}$ de la vigente Constitución española o es, por el contrario, una creación del legislador ordinario sin más fundamento constitucional que el que, de una forma indirecta, le brinda el artículo $9.2^{12}$ ?

La cuestión que acaba de plantearse ha dividido profundamente, en efecto, a la doctrina científica, inclinándose un sector ${ }^{13}$ por la primera de las dos hipótesis planteadas, mientras otros autores ${ }^{14}$ lo hacen por là segunda, sosteniendo que el organismo creado no tiene relación alguna con el artículo 131.2 CE, por tener su fundamento en el artículo $9 \mathrm{CE}$. Hay, incluso, una tercera postura, defendida por el Grupo Socialista y por el Gobierno durante la tramitación parlamentaria del Proyecto de Ley de creación del Consejo, que sitúa el apoyo constitucional en el artículo 105.1 CE ${ }^{15}$. Esta última posición debe ser descar-

1 Art. 131.2-CE: «El Gobierno elaborará los proyectos de planificación de acuerdo con las previsiones que le sean suministradas por las Comunidades Autónomas y el asesoramiento y colaboración de los sindicatos y otras organizaciones profesionales, empresariales y económicas. A tal fin, se constituirá un Consejo, cuya composición y funciones se desarrollarán por ley».

12 Art. 9.2-CE: "Corresponde a los poderes públicos promover las condiciones para que la libertad y la igualdad del individuo $y$ de los grupos en que se integra sean reales y efectivas; remover los obstáculos que impidan o dificulten su plenitud y facilitar la participación de todos los ciudadanos en la vida política, económica, cultural y social's.

13 DURÁN LÓPEZ, F., «Representación de intereses y Comunidades Autónomas", en Informe Pi y Sunyer (1993), Barcelona, 1994, pág. 537; y GARCíA RuIz, J. L., El Consejo Económico y Social: génesis constituyente y parlamentaria, Departamento de Publicaciones del Consejo Económico y Social, Madrid, 1992, pág. 126.

14 SANTANA Gómez, A., "El Consejo Económico y Social español», en VV.AA., Los Consejos Económicos y Sociales, Edit. Trotta, Madrid, 1992, pág. 17; Escudero, R., "El Consejo Económico y Social: un órgano de incierto futuro", en Revista de Relaciones Laborales núm. 17 (1991), pág. 56; y SÁNCHEZ DE VEGA, A., "Primeras reflexiones sobre el Consejo Económico y Social», en REP (nueva época) núm. 80, abriljunio 1993, pág. 163.

15 Vid., en este sentido, el texto del discurso pronunciado por el Ministro de Trabajo y Seguridad Social, Sr. Martínez Noval, en la presentación del Proyec- 
tada de pleno, por cuanto dicho artículo se refiere exclusivamente a la participación, a través del trámite de audiencia, en la elaboración de disposiciones administrativas y no de normas de rango legal ${ }^{16}$. De hecho, en el texto definitivo de la Exposición de Motivos de la Ley 21/1991 no se recoge ninguna referencia expresa ni a ese artículo ni a ningún otro precepto constitucional. Así pues, si descartamos al citado artículo 105.1 CE, el eje central del problema pasa a girar en torno a la cualificación del artículo 131.2 CE como directo sustentador de la creación del CES, existiendo al respecto argumentaciones, tanto a favor como en contra y con mayor o menor fundamentación jurídica, de las que procede dar cumplida cuenta.

\subsection{El artículo 131.2 CE: los argumentos en contra}

Un primer argumento en contra de su fundamentación en el artículo 131.2 viene sustentado en una interpretación restrictiva de una expresión contenida en la Sentencia delTribunal Constitucional 76/1983, de 5 de agosto, que declaraba la inconstitucionalidad de varios preceptos de la Ley Orgánica para la Armonización del Proceso Autonómico (LOAPA). En relación con el artículo 9.2 de este texto legal y en uno de los párrafos de la mencionada Sentencia, el Tribunal afirmaba, en efecto, dentro de su extensa fundamentación jurídica ${ }^{17}$, que era discutible que "al Consejo (del art. 131.2-CE) pueda atribuírsele una función no acorde con el fin que ha determinado su previsión constitucional [...]", y terminaba declarando su inconstitucionalidad.

Una interpretación interesada del párrafo transcrito hace decir al Tribunal Constitucional que el Consejo previsto en el artículo 131.2 sólo puede tener una única función, la participación en la actividad planificadora del Gobierno, que es la prevista constitucionalmente ${ }^{18}$. En

to de Ley de creación del CES ante el Pleno (DSC-P n. ${ }^{\circ}$ 96, de 13 de marzo de 1991 , pág. 4737).

16 En este sentido, Escudero, "El Consejo...», op. cit., pág. 56; y S. DE VEGA, "Primeras...", pág. 164, nota n. ${ }^{\circ} 19$. De igual modo se pronunciaron, durante el debate parlamentario del Proyecto de Ley de creación del CES, el Diputado del Grupo Popular Sr. Baón Ramírez (DSC-P n. ${ }^{\circ} 111$, de 9 de mayo de 1991, pág. 5337) y el Senador del Grupo del Centro Democrático y Social Sr. Martínez Sospedra (DSS n. ${ }^{\circ} 72$, de 4 de junio de 1991, pág. 3924).

17 Vid. Fundamento Jurídico $14 .^{\circ}$ de la STC 76/1983, de 5 de agosto.

18 Vid., en este sentido, el texto de las dos intervenciones del Diputado socialista Sr. Berenguer Fuster, como Portavoz de su Grupo parlamentario, en el 
realidad, lo que hace elTribunal es plantear la discutibilidad del tema, pero no se pronuncia sobre el fondo. La anulación del precepto de la LOAPA se basa, no en la conclusión antecitada, sino en que se crea un mecanismo de resolución de conflictos entre el Estado y las Comunidades Autónomas no previsto constitucionalmente. En definitiva, su inconstitucionalidad deriva de que el legislador, como poder constituído, sobrepasa los límites constitucionalmente impuestos a su potestad legislativa, al reformular el ámbito de competencias definido en nuestra norma suprema, al limitar las potestades atribuídas a diversos órganos y al crear un sistema de control no previsto en la Constitución española ${ }^{19}$.

Así pues, volviendo a lo que nos interesa y como subraya $F$. DURÁN, la referida sentencia del Tribunal Constitucional "no dice, en modo alguno, que no pueda existir un Consejo si no se produce la planificación general de la economía, ni prejuzga cuáles sean las funciones que legalmente puedan atribuirse a dicho Consejo" ${ }^{20}$. En consecuencia, la utilización del pronunciamiento de nuestro Tribunal

debate sobre la Proposición de Ley de creación del CES presentada por la Agrupación Izquierda Unida-Ezquerra Catalana (dentro del Grupo Mixto del Congreso) en fecha 7 de abril de 1987 (DSC-P n. ${ }^{\circ}$ 93, de 15/03/1988, pág. 5842) y en el posterior debate sobre la Proposición no de ley, presentada por el Grupo de Centro Democrático y Social en fecha 26 de octubre de 1988, por la que se insta al Gobierno a que remita a la Cámara un Proyecto de Ley de creación, composición y funciones de un Consejo Económico y Social. En este segundo debate, queda perfectamente resumida la visión del Grupo Socialista sobre el tema: "[...] la posición del Tribunal Constitucional es la de que las competencias del Consejo del número 2 del artículo 131 de la Constitución eran única y exclusivamente unas competencias relativas a la planificación [...]" (vid. DSC-P n. 154, pág. 9273). Esta misma interpretación de la S.T.C. 76/1983 es la que subyace, casi tres años después, en la exposición hecha por el Ministro de Trabajo y Seguridad Social en la presentación ante el Pleno del Congreso del definitivo Proyecto de Ley de creación del CES: "Representaría una incongruencia y un contrasentido que se creara el Consejo previsto en el artículo 131.2 de la Constitución no para cumplir el papel especiffico para el que estaba previsto en ese artículo, que era la planificación global y general de la economía, sino para desarrollar un modelo distinto». Y más adelante reitera: "[...] yo me pregunto, Señorias, si tendría algún sentido crear un órgano que tiene constitucionalmente atribuida una finalidad concreta, finalidad que consiste en la planificación general de la economía" (DSC-P n. 96 , de 13 de marzo de 1991, pág. 4737). A su vez, el Ministro no hace sino asumir lo que ya venía claramente expresado en la Memoria explicativa que acompañaba al mencionado Proyecto de Ley en su tramitación parlamentaria.

19 DURÁN LÓPEZ, "Representación...», op. cit., pág. 535; y GARCía RuIz, El Consejo..., op. cit., pág. 69.

20 DURÁN LÓPEZ, "Representación...», op. cit., pág. 536. 
Constitucional en el sentido antes expuesto no constituye base suficiente para concluir que el Consejo creado no sea el previsto en el artículo 131.2 de la Constitución. Es más, la mayoria doctrinal ${ }^{21}$ se pronuncia abiertamente por la posibilidad de que haya una pluralidad de funciones atribuible al Consejo y no que éste se reduzca a ejercitar én exclusiva la función prevista en dicho precepto. Además, el propio tenor literal de éste ( (... cuya composición y funciones se desarrollarán por ley») parece confirmar esa posibilidad. El asesoramiento y colaboración de los grupos sociales es la única función impuesta por la Constitución como de obligada atribución al Consejo, pero puede verse acompañada de otras, si la Ley de creación, a la que hay remisión constitucional expresa, así lo establece. Destruida, pues, la premisa mayor del silogismo (el Consejo del artículo 131.2 sólo puede tener la función de participar en la planificación general de la economía), debe deducirse que la conclusión obtenida a partir de ella (esto es, que el Consejo legalmente creado, por tener más de esa función, no es el previsto en dicho artículo) no es tampoco válida. Sigue, pues, abierta la polémica sobre el encaje constitucional del CES.

Un segundo argumento en contra lo representa la evidente omisión en la Ley de creación del CES de una referencia al artículo 131.2 como fundamento constitucional del órgano instituido por dicha Ley. Argumento que puede ser complementado con el de que, durante el proceso constituyente, fueron varios los intentos protagonizados por diputados 22 para que el nuevo órgano quedara "bautizado" como Con-

21 Albiñana Cilveti, C., "Las Cortes Generales y el Consejo Económico y Social", en Las Cortes Generales, vol. 1. , Instituto de Estudios Fiscales, Madrid, 1987, pág. 504; BASsols COMA, M., "La planificación económica", en El modelo económico en la Constitución española (dir. F. GARRIDo FALLA), Instituto de Estudios Económicos, Madrid, 1981, págs. 448-449; MAESTRo BuelgA, G., «El momento consensual de la planificación: Notas sobre el Consejo Económico y Social», en REP núm. 82, octubre-diciembre 1993, pág. 83; SÁNCHEZ AGESTA, L., Sistema político de la Constitución Española de 1978, Edersa, Madrid, 1993, pág. 37; y SANTANA Gómez, “El Consejo...", op. cit., pág. 16. En contra, L. CAZORLA, para quien el Consejo sólo puede tener la función de colaborar en la planificación general de la economía; cfr. CAZORLA PRIETO, L. M., "Comentario al artículo 131 ", en Comentarios a la Constitución (dir. F. Garrido Falla), Edit. Civitas, Madrid, 1985, pág. 1933.

22 Así, el Diputado Sr. Carro Martínez, en la enmienda $n .{ }^{\circ} 2$ al entonces artículo 121.2 del Anteproyecto constitucional decía que "el Consejo económico-social que se apunta debe ser bautizado con mayor desarrollo, pues sí es materia típica constitucional", y en muy parecidos términos se expresaba la enmienda presentada por el Diputado Sr. López Bravo (vid. Constitución española. Trabajos preparatorios, Cortes Generales, Madrid, 1980, págs. 128 y 179). Con posterioridad, el Diputado Sr. Fraga Iribarne, en nombre del Grupo de Alianza Popular, recogería la 
sejo Económico y Social, siendo rechazadas todas las enmiendas presentadas en este sentido ${ }^{23}$.

Este segundo argumento no parece de mucho peso, por cuanto lo único que queda claro es la voluntad constituyente de no proceder a nominar al Consejo, remitiendo tal tarea a la ley que, en el futuro, lo fuera a instituir. Así pues, del hecho de que no quiera darle un nombre no puede deducirse que el constituyente prohiba para el futuro que un Consejo Económico y Social se fundamente en el artículo 131.2.

Mayor peso específico tiene el antes mencionado argumento de la falta de referencia expresa al citado artículo por el legislador ordinario que establece el CES. Pero lo curioso es que, como ya quedó expuesto, en la Exposición de Motivos de la Ley 21/1991 tampoco aparece ninguna referencia explícita a otro precepto constitucional.

Implícitamente, si acaso, y sobre la base del texto contenido en el primer y segundo párrafos ${ }^{24}$ de dicha Exposición de Motivos, puede entenderse $-y$ así lo hace ESCUDERO ${ }^{25}$ - que "es el artículo 9.2CE el que ha de identificarse como la cobertura última" de la citada Ley. También en este mismo sentido, afirma A. SÁNCHEZ DE VÉGA ${ }^{26}$ que el CES encuentra su fundamento implícito en el principio orienta-

misma idea para defenderla ante la Comisión de Asuntos Constitucionales y Libertades Públicas, afirmando que «el Consejo [...] no puede quedar en tamaña indefinición, que ni siquiera se le dé un nombre, porque el nombre da el ser a la cosa; [...] que se llame - según una muy autorizada tradición [...] - Consejo Económico y Social" (vid. DSC-C n. ${ }^{\circ} 87$, de 13 de junio de 1978, pág. 3182).

23 El resultado de la votación relativa a la enmienda defendida por el Diputado Sr. Fraga (vid. nota anterior) en la Comisión de Asuntos Constitucionales y Libertades Públicas fue de catorce votos en contra, dos a favor y diecisiete abstenciones (DSC-C n. ${ }^{\circ} 87$, de 13 de junio de 1978, pág. 3189).

24 Según el párrafo $2 .^{\circ}$, "el órgano que se crea [...] refuerza la participación de los agentes económicos y sociales en la vida económica y social, reafirmando su papel en el desarrollo del Estado Social y Democrático de Derecho". A su vez, el párrafo $1{ }^{\circ}$ de la $E$. de $M$. recuerda el mandato constitucional dirigido a los poderes públicos para que promuevan y faciliten la participación de los ciudadanos en la vida económica y social.

25 ESCUDERO, "El Consejo...", op. cit., pág. 56.

26 SÁNCHEZ DE VEGA, "Primeras...", op. cit., pág. 163. Algún otro autor añade al artículo 9.2, como fundamento implícito del CES, el artículo 105-CE. Así, F. MADRID, para quien "aunque la Ley [de creación del CES] no cita expresamente estos preceptos, se está refiriendo a los arts. 9.2 y 105 de la Constitución". Cfr. MADRID CONESA, Naturaleza juridica..., op. cit., pág. 17. En nuestra opinión, y según ya hemos argumentado en el texto, el artículo 105-CE no puede servir, en ningún caso, como fundamento constitucional del CES. 
dor de la actuación de los poderes públicos, que consagra el artículo 9.2-CE y que se concreta en la remoción de obstáculos para facilitar la participación de todos los ciudadanos en la vida política, económica, cultural y social.

Ahora bien, aun admitiendo esta hipótesis, ¿puede afirmarse que con ella queda excluida la fundamentación en el artículo 131.2 CE? En nuestra opinión, la respuesta debe ser negativa, por cuanto este último artículo no es sino una manifestación más del artículo $9.2 \mathrm{CE}$, por lo que, aun cuando se reconociera explícitamente la relación entre el Consejo y el tan repetido artículo 131.2, el fundamento último del órgano creado no por ello dejaría de ser el citado artículo 9.2. Quiere esto decir que el apoyo constitucional de este precepto es genérico y no debe ser, por tanto, excluyente de otro encaje constitucional más específico ${ }^{27}$, cual sería el del artículo 131.2, a menos que expresamente así lo hubiera afirmado el legislador ordinario. Dado el silencio de éste al respecto, lo único que puede deducirse del texto de la Exposición de Motivos es que el legislador ha hecho una implícita referencia al fundamento genérico o indirecto del Consejo, sin haber querido aludir, por razones que se nos ocultan, al apoyo específico que también pudiera tener. Como indica el aforismo latino, «el que calla, nada dice». De esta forma, el silencio del legislador nada añade ni quita a la posibilidad de un encaje constitucional más especifico que el brindado, de forma más genérica, por el artículo 9.2 de la Constitución. En definitiva, la falta de pronunciamiento expreso del legislador ordinario sobre la cuestión la deja, sin duda, abierta a otras interpretaciones.

Existe todavía un tercer argumento en contra, que igualmente viene proporcionado por una determinada interpretación del texto del artículo $131.2^{28}$. Cabría, en efecto, deducir de su lectura que en el Consejo previsto en él deben integrarse también las Comunidades Autó-

27 En este mismo sentido se pronuncia J. L. García RuIz en El Consejo..., op. cit., pág. 125: «[...] pero sin perjuicio de utilizar esta cobertura genérica, ¿por qué no acudir también en cada caso a la cobertura participativa especifica que para supuestos concretos articula la Constitución?"; e igualmente F. DURÁN, para quien en el art. 131.2-CE "se concretan, para las cuestiones económicas y sociales, las previsiones genéricas de participación que la Constitución consagra en el artículo 9.2». Cfr. DURÁN LóPEZ, "Representación...», op. cit., pág. 531.

28 Para C. AlBiñana, cabe hacer una doble interpretación del artículo 131.2CE. Por un lado, una interpretación "flexible y extensiva", que permite la presencia de las Comunidades Autónomas en el Consejo; $y$, por otro lado, una interpretación restrictiva, excluyente de tal presencia. Cfr. AlBIÑANA CILVETI, "Las Cortes Generales...», op. cit., págs. 496-497. 
nomas ${ }^{29}$, por entenderse que la expresión «a tal fin» se refiere no sólo a la función "de asesoramiento y colaboración", sino también al suministro de previsiones por dichas Comunidades ${ }^{30}$. Sobre esta premisa, como en el CES no están integradas las Comunidades Autónomas, éste no puede ser el órgano previsto para la planificación general de la economía ${ }^{31}$.

Frente a este razonamiento debe señalarse que el propio término "previsiones», gramaticalmente hablando, hace alusión a un momento temporal anterior a la fase de "asesoramiento y colaboración". Por ello, no puede darse una coincidencia temporal de ambas fases ${ }^{32}$. La secuencia lógica de elaboración de un hipotético proyecto de ley planificadora comenzaría por el suministro al Gobierno de las previsiones de planificación por parte de las Comunidades Autónomas, seguiría por la redacción del correspondiente anteproyecto y terminaría con el sometimiento de éste al dictamen del Consejo. No es posible, pues, defender que las previsiones se proporcionen coetáneamente a la función asesora $y$, por tanto, no cabe hablar de un Consejo donde estén representadas, al mismo tiempo,

29 Ésta es la postura mantenida, durante la tramitación parlamentaria del Proyecto de Ley de creación del CES, por Eusko Alkartasuna en las enmiendas núms. 22, 23, 25 y 26 (DSC-P n. ${ }^{\circ}$ 96, de 13 de marzo de 1991, págs. 4738-4739), por Izquierda Unida en la enmienda $n .^{\circ} 53$ (DSC-P n. ${ }^{\circ} 96$, de 13 de marzo de 1991, pág. 4741) y por el Grupo Popular en la enmienda n. 95 (DSC-P n. ${ }^{\circ} 96$, de 13 de marzo de 1991, pág. 4743). Por su parte, Euskadiko Eskerra, en la enmienda n. $^{\circ} 36$, propugna la integración en el CES de una representación de cada Consejo regional. Para un mayor detalle de las distintas posiciones mantenidas al respecto por los distintos Grupos parlamentarios, durante la tramitación del Proyecto de Ley de creación del CES, vid. GARcia RUIz, "El Consejo...", op. cit., págs. 107-108. Tres años después de la creación del CES, con ocasión del debate sobre la situación del Estado de las Autonomías, celebrado en el Senado el 26 de septiembre de 1994, todavía se propugna por la Xunta de Galicia la integración de las Comunidades Autónomas en el Consejo, mediante la reforma de la Ley $21 / 1991 ;$ vid. Informe de la Xunta de Galicia, parte III («El Consejo Económico y Social: cumplimiento del artículo 131 de la Constitución»), ejemplar mecanografiado, pág. 40.

30 En este sentido, Martínez Abascal y Rojo TorReCILLA, "Participación...., op. cit., pág. 143.

31 Afirma, en este sentido, R. AgulLera que «el CES [...] se alejó de las prescripciones del artículo 131.2-CE, al diseñarse legalmente como un 'órgano consultivo del Gobierno en materia socioeconómica y laboral' (art. 1.2), sin conexión ni relación directa alguna con las Comunidades Autónomas". Cfr. AguILERA IzouIERDo, R., «El Consejo Económico y Social nacional, los Consejos Económicos y Sociales autonómicos y los Consejos de Relaciones Laborales», en REDT núm. 90 (1998), pág. 564.

32 En este sentido, García RuIz, "El Consejo...», op. cit., pág. 128. 
las Comunidades Autónomas y las organizaciones de intereses sectoriales ${ }^{33}$.

Además, como indica F. DURÁN ${ }^{34}$, esta integración en el CES de las Comunidades Autónomas disminuiría su rango constitucional, argumento al que C. ALBIÑANA añade el de que la presencia de los entes autonómicos "podría transformarlo en escenario arbitral para la transacción entre las exigencias del Plan general y las pretensiones regionales» 35 , lo que llevaría a sobrepasar el campo de actuación propio del Consejo (que es el de asesorar y colaborar en la planificación general). En consecuencia, el hecho de que no se integren en el CES las Comunidades Autónomas no constituye tampoco base suficiente para afirmar la desvinculación entre ese instituto y el artículo 131.2.

\subsection{El artículo 131.2 CE: los argumentos a favor}

Una vez examinados y desechados los distintos argumentos esgrimidos contra el encaje constitucional del CES en el artículo 131.2, procede que busquemos ahora razones que permitan demostrar lo contrario, esto es, la vinculación entre el CES y el tan repetido precepto constitucional. En este sentido, J. L. GARCÍA RUIZ ha basado su opinión favorable a tal vinculación en la identificación ${ }^{36}$ que hace entre la actividad planificadora a que alude dicho precepto y la actividad de programación que lleva a cabo el Gobierno a través de los proyectos de ley que presenta para su tramitación ante las Cámaras legislativas.

33 Esta postura es defendida, durante la tramitación del Proyecto de Ley de creación del CES, por los Grupos parlamentarios nacionalistas (del Partido Nacionalista Vasco y de Convergencia y Unión) y por el Grupo del Centro Democrático y Social, además, por supuesto, de por el Gobierno autor del Proyecto y por el Grupo parlamentario socialista, que lo apoya. Se trata, para los nacionalistas fundamentalmente, de una "cuestión de dignidad». La forma cómo se pronuncia el Portavoz de Minoría Catalana, Sr. Hinojosa Lucena, resulta clarificadora al respecto: "Consideramos que las Autonomias deben entenderse con el Gobierno del Estado a otro nivel, no a nivel de un Consejo consultivo" (DSC-P n. ${ }^{\circ} 96$, de 13 de marzo de 1991, pág. 4751). En la misma línea, el Portavoz del Grupo Vasco, Sr. Olabarría Muñoz, manifiesta que uun partido político nacionalista no aspira a participar en órganos de naturaleza consultiva, sino en los de carácter ejecutivo" (DSC-P n. 111, de 9 de mayo de 1991, pág. 5343).

34 DURÁN LÓPEZ, «Representación...» op. cit., pág. 540.

35 Albiñana CilvetI, "Las Cortes Generales...», op. cit., pág. 497.

36 Esta misma idea identificadora de ambas actividades es defendida por Bassols CoMA en "La planificación...", op. cit., págs. 421-422. 
De esta forma, al instituirse por ley un órgano consultivo para que participe en la elaboración de esos "actos de carácter programático-planificador" que son los proyectos de ley, tal órgano no puede ser otro que el previsto en el artículo 131.2 de la Constitución. Caso de que un futuro Gobierno quisiera verificar una planificación general de la economía, el Consejo que, según mandato constitucional, debe colaborar en ella ya estaría "constituido y actuante» ${ }^{37}$.

Aceptando el razonamiento expuesto, aun sin dejar de reconocer que parte de una afirmación (la actividad ordinaria del Gobierno como forma de planificación general) que es, en principio, discutible, creemos que existe un segundo argumento de mayor contundencia también favorable al encaje constitucional del Consejo en el artículo 131.2. Este argumento consiste sencillamente en combinar el juego de cuatro normas jurídicas, a saber: el artículo 7 de la Ley 21/1991, relativo a sus funciones, y los artículos 31.2, 103 y 131.1 de la Constitución española.

En virtud del primero de los artículos citados, es función del Consejo emitir dictamen con carácter preceptivo sobre cualquier anteproyecto de ley estatal que regule materias socio-económicas o laborales. Por su parte, el artículo 131.1 del texto constitucional permite al Estado planificar la economía general, pero con la condición de que, si se decide a hacerlo, debe acudir a la ley ordinaria como instrumento de normación planificadora. Parece claro que esa hipotética ley de planificación debe afectar, sin duda, a intereses socio-económicos del Estado, por lo que, considerando la amplitud con que está redactado el ya citado artículo 7 de la Ley de creación, no hay ningún inconveniente en admitir que el CES dispondría de la competencia necesaria para emitir el preceptivo dictamen sobre el correspondiente anteproyecto de ley planificadora, cumpliendo con ello la función de "asesoramiento y colaboración de los sindicatos y otras organizaciones profesionales, empresariales y económicas», ya que tanto unos como otras tienen - como es sabido - representación en el Consejo.

37 García RuIz, «El Consejo...», op. cit., pág. 127. En parecidos términos se pronuncia F. DURÁN, para quien "el CES creado por la Ley 21/1991 es, con independencia de la voluntad subjetiva del legislador, el Consejo previsto en el artículo 131.2-CE, de tal manera que no sería jurídicamente posible la creación de otro Consejo al amparo de esa norma, y si se decide en el futuro planificar la actividad económica general, la labor de asesoramiento y colaboración constitucionalmente exigida debería ser encomendada al CES". Cfr. DURÁN LÓPEZ, "Representación...», op. cit., págs. 537-538. 
Ahora bien, esta genérica competencia funcional no basta para afirmar que dicho órgano sea el previsto en el artículo 131.2, toda vez que el Gobierno podría proponerse crear otro Consejo distinto del CES, al que atribuiría la competencia específica de colaborar en la planificación general, sustrayéndola, por tanto, del genérico ámbito competencial del CES definido por el artículo 7 de la Ley 21/1991. Pues bien, es aquí donde entra en juego el artículo 103 de la Constitución, toda vez que, al obligar a la Administración a servir con objetividad los intereses generales, está exigiendo una actuación conforme a las reglas básicas que impone la lógica organizativa y una de estas reglas es, precisamente, la de economía del gasto. Y ello porque, en coherencia con el principio de legitimidad racional que preconizara MAX WEBER, la Administración "ha de realizar sus fines conforme no sólo a la legalidad formal (racionalidad jurídica), sino también de modo eficiente (racionalidad económica y técnica) ${ }^{38}$. Refuerza, además, esta exigencia el artículo 31.2 de la Constitución española cuando prescribe que la programación y ejecución del gasto público uresponderán a los principios de eficiencia y economian. Es decir, si el Gobierno, como cabeza que es de la Administración Pública, debe escoger entre dos soluciones igualmente eficaces para resolver un problema determinado, siempre debe preferir la que menos gasto ocasione al erario público. Aplicando, pues, esta regla de oro de la economía organizativa, resulta evidente que no es factible, por antieconómica, la solución de crear un órgano asesor nuevo, existiendo ya otro (el CES) con posibilidades de prestar exactamente la misma función asesora, por cuanto ésta se halla dentro del ámbito competencial genéricamente definido por el artículo 7 de la Ley 21/1991. Dicho con otras palabras, si el Gobierno opta por planificar, está obligado, sobre la base de lo dispuesto en los artículos 31.2 y 103 de la Constitución, a contar con el CES como órgano asesor y colaborador en la planificación, por cuanto es ésta la solución más económica $y$, por tanto, la que mejor sirve a los intereses generales. El Consejo no sólo puede, sino que debe intervenir en la planificación general de la economía. De ahí que tengamos que considerar al CES como el órgano previsto en el artículo 131.2 de la Constitución. Su encaje constitucional ${ }^{39}$ en este precepto

38 López Pellicer, J. A., Lecciones de Derecho Administrativo, Edit. Promociones y Publicaciones Universitarias, Murcia, 1987, pág. 38.

39 Este mismo modo de encajar constitucionalmente al CES es asumido, si bien con una argumentación sumamente vaga, por el propio Consejo en su Dictamen $n .^{\circ} 7 / 1995$, aprobado en la sesión extraordinaria del Pleno de 26 de octubre de 1995. En las Consideraciones de dicho Dictamen se afirma, en efecto, que 
queda, de este modo, afirmado mediante una, a nuestro parecer, sólida argumentación jurídica. Y como lógica consecuencia de tal encaje, debemos propugnar la caracterización del CES como «órgano de relevancia constitucional».

\section{EL PROBLEMA DE LA DELIMITACIÓN CONCEPTUAL ENTRE DICTAMEN E INFORME}

El segundo de los problemas que debe afrontar un análisis jurídico del CES es el de la falta de una concreta delimitación entre sus dos más conocidos instrumentos formales de expresión. Parece claro, en efecto, que los términos "dictamen" e "informe" responden a realidades conceptualmente distintas, entre otras razones porque tanto los textos normativos reguladores del CES como la propia práctica de éste hasta la fecha actual hacen constantes referencias a uno y otro término de forma netamente diferenciada. Sin embargo, resulta imposible encontrar en dichos textos una definición básica de lo que cada uno de tales términos representa esencialmente.

Para el legislador español, dictamen e informe son dos vías diferentes de expresión, pero su respectivo concepto lo da por sentado y, por tanto, como sabido de antemano para los destinatarios de la nor$\mathrm{ma}$, lo que le exime, en consecuencia, de la tarea de definirlos ${ }^{40}$. Ello nos obliga a realizar la pertinente indagación jurídica a la búsqueda de sus respectivos conceptos.

"la creación del Consejo Económico y Social responde al mandato que la Constitución en su artículo 9.2 dirige a los poderes públicos, (...) mandato que se concreta, para los aspectos económicos y sociales, en el artículo 131.2 de la propia Constítución". Vid. el fascículo correspondiente al Dictamen 7/1995, editado por el CES, pág. 2.

40 Tampoco en la Ley Orgánica 4/1980, de 22 de abril, reguladora del Consejo de Estado, aparece referencia alguna a lo que debe entenderse por dictamen, si bien en este caso resulta perfectamente comprensible por cuanto para este Consejo no existe otro vehículo de expresión distinto del dictamen. De ahí que podamos identificar a éste, sobre la base de un sencillo razonamiento lógico, como el instrumento jurídico-formal donde se recoge la opinión del Consejo sobre el asunto que le es sometido a consulta. Obsérvese, no obstante, que aquí el término «dictamen" tiene carácter ambivalente, pues se refiere tanto a lo sustantivo, en cuanto que equivale a «opinión», como a lo formal, en cuanto que constituye el único cauce adecuado para expresar tal opinión. 


\subsection{El planteamiento teórico del problema}

El primer paso que, sin duda, ha de darse en tal proceso indagatorio lo constituye la lectura del Diccionario de la Real Academia Española para averiguar cuál es el sentido o la significación que, en el lenguaje común, tienen los diversos términos relacionados con el problema que ahora nos ocupa. En este sentido, la definición que del verbo «informar» hace la Real Academia de la Lengua, en la acepción que aquí nos interesa, es la de «dictaminar un cuerpo consultivo o un experto sobre materia de su competencian, mientras que la de "informe» es "acción y efecto de informar o dictaminar». Por su parte, la voz "dictaminar» equivale a "dar opinión» y el vocablo "dictamen" es entendido como «opinión o juicio que se forma o emite sobre una cosa". Sobre la base, pues, del lenguaje común, cuya significación nos brinda el Diccionario de la Real Academia de la Lengua, la confusión entre ambos términos resulta evidente. Parece entonces necesario recurrir a un lenguaje más especializado, como es el jurídico, para tratar de conocer los matices diferenciales que los separan.

Desde la perspectiva jurídica y, concretamente, en la normativa reguladora del CES, los términos "dictamen» e «informe» reciben un tratamiento más formal que sustantivo, siendo considerados, más que por lo que sustantivamente son (como hace el Diccionario de la RAE), por su función como cauces formales de expresión de lo sustantivo (esto es, de los resultados de la actividad desarrollada por el CES). Este planteamiento "formalista" sirve para eludir la confusión a que conducia el lenguaje común, pues nos hallamos, ciertamente, ante dos diferentes instrumentos jurídico-formales de expresión del CES, a pesar del defectuoso tenor literal del artículo 6.1.d) de la Ley ${ }^{41}$, que parece oponerse a la cualificación del informe como soporte vehicular de la opinión del Consejo. Pero, aun dando por sentada dicha cualificación, el problema, en cualquier caso, sigue en pie: ¿cómo se traza la línea divisoria entre ambos?

Teóricamente hablando, tres criterios podrían servir para deslindar uno y otro término: el del objeto sobre el que recaen; el del sujeto que toma la iniciativa de elaborarlos; y el de su finalidad. El primero de tales criterios queda inutilizado por nuestro legislador desde el momento en que establece con una extraordinaria amplitud el posible

41 A tenor de lo dispuesto en este artículo, "los pareceres del Consejo se expresarán bajo la denominación de "dictamen del Consejo Económico y Social" y no serán vinculantes». 
objeto de los dictámenes facultativos: «los asuntos que [...] se sometan a consultan (art. 7.1.2-LCES). Como uno cualquiera de tales "asuntos" puede, a su vez, formar parte de alguna de las específicas materias que, con no menor amplitud, son relacionadas en el artículo 7.1.342 de la Ley 21/1991 como posible objeto de informe o estudio, resulta evidente que el criterio del objeto deviene inservible para efectuar la delimitación requerida. Algo semejante ocurre con el segundo de los referidos criterios - el del sujeto de la iniciativa - , que debe ser igualmente desechado, por cuanto que, si bien la iniciativa de elaborar un dictamen sólo puede partir del Gobierno ${ }^{43}$ (o de cualquiera de sus miembros), la de elaborar un informe o estudio se halla, en cambio, tanto en manos gubernamentales como en las del propio Consejo, lo que conduce, lógicamente, a que este criterio de deslinde quede inutilizado como tal. Sólo resta, pues, para delimitar ambos instrumentos jurídico-formales, acudir al tercero y último de los criterios antes mencionados, esto es, el basado en la finalidad que cada uno de ellos persigue.

A este respecto, el artículo 6.1.d) de la Ley 21/1991, al que antes hacíamos alusión, prescribe que "los pareceres del Consejo se expresarán bajo la denominación de "dictamen del Consejo Económico y Social" "44. Una interpretación literal de este precepto nos llevaría, según decíamos, a eliminar al informe como cauce de expresión de la opinión del Consejo, lo que, sin duda, resolvería la cuestión planteada, toda vez que el dictamen quedaría conectado, de modo exclusivo ${ }^{45}$,

42 Según este artículo, puede ser objeto de informe cualquier asunto relacionado con alguna de las siguientes materias: Economía; Fiscalidad; Relaciones Laborales; Empleo y Seguridad Social; Asuntos Sociales; Agricultura y Pesca; Educación y Cultura; Salud y Consumo; Medio Ambiente; Transporte y Comunicaciones; Industria y Energía; Vivienda; Desarrollo Regional; Mercado Único Europeo y Cooperación para el Desarrollo.

43 Como se verá un poco más adelante (vid. infra, pág. 611), en la práctica esta facultad exclusiva del Gobierno es compartida por el CES.

44 En el mismo sentido, el artículo 45.1-ROFICES.

45 La exclusividad del dictamen como cauce formal de expresión es nota característica de la legislación comunitaria relativa al Comité Económico y Social de las Comunidades Europeas, donde existen importantes diferencias funcionales entre el documento informativo y el dictamen. El primero, en efecto, se contempla en el art. 26 del Reglamento interno y consiste en un trabajo de recopilación de datos que ordena emprender el Comité, por iniciativa de su Mesa, sobre un asunto o materia relativa a las tareas encomendadas a la Unión Europea. Se trata de un documento interno, sin relevancia externa, que elabora una Sección del Comité y cuya finalidad no es otra que la de investigar y recopilar datos sobre un deter- 
a la finalidad de servir como cauce formal de expresión del parecer del Consejo, mientras que el informe cumpliría la finalidad, ya expuesta con anterioridad, de recopilar y sistematizar los datos disponibles sobre un determinado asunto de carácter socio-económico o laboral. Sin embargo, esta interpretación literal del precepto citado chocaría, en nuestra opinión, no sólo con la propia práctica del CES, que viene incluyendo habitualmente sus opiniones en los informes que elabora, sino también con la Exposición de Motivos de la Ley 21/1991, que señala, como una de las líneas básicas informadoras del nuevo organismo consultivo, la posibilidad que tiene el CES de elaborar, por propia iniciativa, "informes o estudios sobre una serie de materias que expresen la opinión de este órgano en relación con las mismas». No creemos, por tanto, que nuestro legislador haya querido privar al informe de su capacidad para expresar la opinión del Consejo. Muy al contrario, entendemos que su concepción sobre el dictamen y el informe sigue las líneas directrices trazadas por los Derechos francés e italiano, en los que dictamen e informe comparten, con los matices diferenciales que veremos a continuación, la cualidad de servir como vehículos de expresión de las opiniones emitidas por los correspondientes órganos consultivos.

En la normativa reguladora del Conseil économique et social francés, el avis (dictamen) constituye la manifestación del parecer del Conseil sobre determinados proyectos normativos del Gobierno, mientras que el ètude (del que deriva, sin duda, el término "estudio" utilizado por el legislador español como equivalente a «informe») no es sino una recopilación documentada de información, a la que, circunstancialmente, puede añadirse, por decisión del Gabinete del Conseil, la opinión de éste sobre el asunto objeto de la información ${ }^{46}$. En el

minado asunto, por lo que no sirve para recoger la opinión del Comité. En cambio, los dictámenes vienen definidos por el art. $\mathbf{4 7 . 2}$ del mismo Reglamento como «documentos breves en los que se formulará una opinión motivada sobre la propuesta de la Comisión [Europea] o el asunto que constituya el objeto de la consulta". Así pues, mientras el documento informativo contiene un conjunto sistematizado de datos sobre un asunto o materia, el dictamen siempre contiene una opinión del Comité. La separación entre ambos es tan tajante que, cuando en el curso de la elaboración de un documento informativo se considere que pueda resultar de interés, la Mesa, a petición de la Sección que lo elabora, podrá proponer al Pleno del Comité que se modifique la naturaleza jurídica del trabajo recopilatorio de datos y se elabore un dictamen de iniciativa propia, en el que pueda recogerse la opinión del Comité. Vid. al respecto, SerRa Cristóbal, R., El Comité Económico y Social de las Comunidades Europeas, Edit. McGraw-Hill, Madrid, 1996, pág. 73.

46 Vid. Martínez Abascal, V.; Pérez Amorós, F., y Rojo Torrecilla, E., Los Consejos Económicos y Sociales (España y otros países comunitarios), Edit. Ibidem, Madrid, 1993, pág. 170. 
modelo francés, por tanto, el ètude puede servir eventualmente de cauce formal para expresar la opinión del Conseil.

Inspirado en las mismas pautas que el Derecho francés, también el ordenamiento italiano consagra una clara distinción entre el dictamen, que sirve para expresar la opinión del Consiglio nazionale dell'economia e del lavoro, y el informe, cuyo principal objetivo es el de compendiar, describir y sistematizar documentación o datos, pero en el que cabe incluir un análisis de los mismos, en el que pueden verterse las opiniones o valoraciones del Consiglio 47 . Vemos, pues, cómo dictamen e informe se diferencian en la legislación italiana por su respectiva finalidad principal.

¿Cabe transplantar el anterior criterio delimitador entre dictamen e informe al ámbito de nuestro Consejo? La respuesta debe ser, a nuestro modo de ver, afirmativa. El legislador español parte, en efecto, de la misma distinción que hacen los legisladores francés e italiano, identificando al dictamen con la emisión de una opinión o, lo que es lo mismo, con el ejercicio de la función consultiva en su sentido más estricto, y al informe o estudio con la investigación y sistematización de datos sobre un asunto determinado. Ahora bien, permite igualmente una cierta flexibilidad del informe, admitiendo que en el análisis de los datos obtenidos en el curso de la obligada investigación se incluyan opiniones o valoraciones, bien entendido que éstas, en buena lógica, no dejan de ser un elemento secundario dentro del informe, cuyo objetivo primordial se centra en la obtención de datos para proporcionar la adecuada información sobre un asunto. Tal concepción del informe habilita a éste, por tanto, para servir como cauce de expresión del Consejo en el ejercicio de la función consultiva, la cual es entendida, consecuentemente, por nuestro legislador en un sentido muy amplio ${ }^{48}$. Por su parte, el dictamen es concebido como el normal y más apropiado vehiculo de expresión del parecer del Consejo, si bien ello no obsta para que dentro del dictamen se pueda encontrar, como elemento secundario, una labor investigadora y recopiladora de datos, cuyo resultado constituya, precisamente, la base sobre la que el Consejo delibere y dictamine.

Así pues, para el legislador español, al igual que para el francés o el italiano, la frontera entre el dictamen y el informe aparece con una

47 Vid. Martínez Abascal [et al.], Los Consejos..., op. cit., pág. 247.

48 En nuestra opinión, de la regulación contenida en la Ley 21/1991 se deduce que, dentro de la función consultiva del CES, se hallan incluidas no sólo la emisión de dictámenes, sino también la elaboración de informes y de la memoria anual sobre la situación socio-económica y laboral española. 
cierta "permeabilidad", toda vez que, para llegar a concretar un criterio delimitador basado en la distinta finalidad principal que uno $y$ otro persiguen, parece imprescindible realizar un previo juicio de valor, en orden a calibrar el grado de relevancia que adquiere la tarea valorativa o de opinión a desarrollar por el Consejo frente a la labor investigadora y de recopilación de datos. En el dictamen, que se dirige primordialmente a expresar la opinión del Consejo, aquella tarea deviene fundamental; en cambio, en el informe o estudio aparece como elemento principalísimo la mencionada labor de investigación $y$ recopilación de datos, sin perjuicio de que en él pueda incluirse (y, de hecho, asi viene sucediendo) el parecer del Consejo como elemento secundario. Sólo sobre la base de esta concepción flexible de la frontera entre dictamen e informe, que es, según nuestra opinión, la sustentada por el legislador español, puede evitarse la imposición del dictamen como única y exclusiva forma de expresión de las opiniones del Consejo, imposición a la que llevaría de modo obligado -según veíamos-una interpretación literal del artículo 6.1.d) de la Ley 21/1991.

Dicho sea con otras palabras, la obligatoriedad de la forma de dictamen viene determinada, más que por expresar la opinión del Consejo (ya que ésta puede también constituir un contenido secundario del informe), por el hecho de que su finalidad esencial sea, preferente $y$ precisamente, dar a conocer al órgano consultante dicha opinión. Por el contrario, se impone el informe como vía de expresión cuando el interés dominante sea el de obtener información acerca de un determinado asunto de índole socio-económica, sin perjuicio de que en tal informe pueda incluirse la valoración u opinión del Consejo sobre dicho asunto. De esta forma, el CES, al elaborar un informe, tiene la posibilidad de cumplir un doble objetivo: el principal de obtener los datos relativos a un determinado asunto $o$ problema socio-económico y, en su caso, proporcionar al órgano consultante la información solicitada; y el secundario de expresar su opinión a través del propio informe, tal y como parece querer el legislador español en el antecitado párrafo de la Exposición de Motivos de la Ley 21/1991. Voluntad legislativa que podría deducirse igualmente de su propio articulado cuando dispone que en la Memoria anual, que no deja de ser un especial tipo de informe ${ }^{49}$, el Consejo debe exponer "sus consideraciones sobre la situación socio-económica y laboral 
de la Nación" ${ }^{50}$. La utilización del término "consideraciones", que equivaldría, en nuestra opinión, a "valoraciones" u "opiniones", nos da la suficiente base para la afirmación que, interpretando la voluntad del legislador, acabamos de efectuar.

\subsection{Planteamiento del problema en la práctica del CES}

Establecida, pues, la pauta legal para delimitar, en sede teórica, los dos principales instrumentos con que cuenta el CES para manifestar ad extra su opinión, cabe preguntarse si en la práctica desarrollada hasta la fecha se ha venido haciendo un uso de ambos instrumentos jurídico-formales acorde con lo querido por el legislador. En este sentido, si efectuamos un análisis de los dictámenes e informes emitidos por el CES, debe admitirse que, en líneas generales, la respuesta ha de ser afirmativa. Hay que señalar, empero, que en ocasiones se da una práctica del CES que, a nuestro entender, se aparta de lo querido por el legislador. Tal práctica consiste en utilizar la facultad de elaborar informes de propia iniciativa para, bajo esa apariencia formal, emitir verdaderos dictámenes sobre asuntos o proyectos legislativos que, en su día, no fueron sometidos por el Gobierno a consulta del Consejo. En tales casos, estimando éste dicha consulta como legalmente obligatoria por afectar a materia socio-económica, intenta paliar el "olvido" gubernamental elaborando auténticos dictámenes, que se esconden bajo la apariencia de informes o estudios de propia iniciati$\mathrm{va}^{51}$. Aun dando por cierta tal omisión del deber legal exigible al Gobierno, no parece que la reacción jurídicamente deseable sea la protagonizada por el Consejo, toda vez que, en nuestra opinión, la pre-

50 Art. 7.1.5-LCES.

51 Como ejemplos del inadecuado uso del informe a que se hace referencia en el texto, pueden servir los siguientes: el Informe 1/1995 sobre el Proyecto de Ley de Vías Pecuarias, aprobado por el Pleno en su sesión del día 15 de febrero de 1995; el Informe 2/1995 sobre el Plan Director de Infraestructuràs 1993-2007, aprobado por el Pleno en su sesión del día 22 de marzo de 1995; y el Informe 6/1996 sobre el Plan de Reconversión Regional y Social (2. ${ }^{a}$ Fase, 1997-1999) para las Regiones incluídas en el Objetivo $n .^{\circ} 2$, aprobado por el Pleno en su sesión del día 23 de octubre de 1996. En este último informe se viene, incluso, a reconocer expresamente que se elabora en sustitución del dictamen que debiera haber sido requerido por el Gobierno: "Ante la ausencia de solicitud expresa de elaboración de un Dictamen sobre el Plan, [...] se decide emitir, previo análisis y tramitación por la Comisión de Mercado Único, Desarrollo Regional y Cooperación al Desarrollo, un Informe sobre el mismo». 
sumible ilegalidad de la omisión gubernamental no puede ser legalmente contestada con otra irregularidad administrativa. Dictamen e informe - según acabamos de ver- deben cumplir sus respectivas finalidades $y$, tal como en nuestra argumentación cabe deducir de la Ley, el dictamen constituye la exclusiva forma a través de la que el Consejo debe manifestar su opinión (respecto de la parcela de la actividad normativa del Gobierno que le compete por razón de la materia) en aquellos casos en que el interés dominante sea, precisamente, esa manifestación. En otras palabras, el informe - de acuerdo con lo legalmente previsto - no puede tener como finalidad principal la de recoger la opinión del CES sobre un determinado asunto o proyecto legislativo, pues ello corresponde exclusivamente al dictamen. De ahí que consideremos jurídicamente inviable que el informe asuma, por sustitución no prevista legalmente, el papel reservado al dictamen en aquellos casos en que se omita indebidamente la consulta al Consejo. Sin duda existen otras vías, de mayor validez desde la perspectiva jurídica, a través de las cuales pueda lograrse del Gobierno el pleno respeto del derecho que tiene reconocido el CES a participar en la tarea legiferante del Estado en materia socio-económica. Aún más, al ser consciente, posiblemente, de tal irregularidad jurídica, el Consejo ha terminado, en una especie de "huida hacia adelante», por autoconcederse la competencia de emitir dictámenes de iniciativa propia sobre proyectos de ley que, referidos a materia socio-económica, no habían sido sometidos por el Gobierno, en su fase de anteproyectos, a la preceptiva consulta del CES. Dado que la ampliación de sus competencias debe verificarse mediante ley, debemos concluir que estos dictámenes son, desde la perspectiva jurídico-administrativa, si no nulos de pleno derecho, sí al menos anulables ${ }^{52}$, ya que se prescinde de uno de sus trámites legales (la solicitud de consulta que debe formular el Gobierno). En la práctica, es posible, sin embargo, que puedan ejercer su influencia sobre el legislador ordinario, ya que la publicación de esos dictámenes se hace de la misma forma que los jurídicamente válidos y la opinión del CES puede, por tanto, llegar a ser oída por los miembros de las Cámaras legislativas en que haya de debatirse y aprobarse el proyecto de ley indebidamente dictaminado por el CES. Creemos que es ésta, sin duda, la finalidad perseguida, pero, en cual-

52 Vid. el art. 63, en relación con el art. 62.1.e), de la Ley 30/1992, de 26 de noviembre, de Régimen Jurídico de las Administraciones Públicas y del Procedimiento Administrativo Común (BOE ${ }^{\circ}{ }^{2} 285$, de 27/11/92). 
quier caso, la licitud del fin a conseguir nunca puede justificar el empleo de medios irregulares.

\section{LA DETERMINACIÓN DEL ÁMBITO OBJETIVO DEL DICTAMEN}

La función consultiva por excelencia, aquélla sobre la que gira fundamentalmente la actividad de cualquier órgano consultivo, es la emisión de dictámenes. Según la regulación legal del CES, los dictámenes que éste emita pueden revestir el carácter de preceptivos o de meramente facultativos, no siendo, en ningún caso, vinculantes ${ }^{53}$. El órgano encargado de aprobarlos es el Pleno, si bien cabe la posibilidad de que delegue ocasionalmente esta competencia en la Comisión Permanente ${ }^{54}$, correspondiendo la iniciativa para proponer (al Pleno) dicha delegación al Presidente o a once Consejeros ${ }^{55}$. Hasta aquí no se plantean, según puede observarse, ningún tipo de problemas. Las dificultades comienzan, sin embargo, a la hora de aplicar las normas reguladoras del dictamen preceptivo, como vamos a comprobar de inmediato.

Los dictámenes preceptivos aparecen regulados en el artículo 7.1.1 de la Ley 21/1991, que determina los distintos supuestos en que procede su emisión. De los cinco previstos en dicho artículo, hay tres supuestos en los que cabe detectar diversos problemas, fundamentalmente referidos a la determinación del ámbito objetivo de aplicación del dictamen preceptivo.

El primero de tales supuestos conflictivos lo constituyen los dictámenes sobre anteproyectos de leyes estatales y proyectos de Reales Decretos legislativos, que regulen materias socio-económicas $y$ laborales ${ }^{56}$. Puede observarse que en este caso el ámbito de aplicación del dictamen queda delimitado por dos criterios: el material, ya que ha de tratarse de anteproyectos que se refieran, en exclusiva, al campo socio-económico o laboral, debiendo determinarse por el Gobierno cuando se incide en ese campo; y el subjetivo, pues el dictamen recae sobre la actividad realizada por el Gobierno en el ámbito de la producción normativa, con dos únicas excepciones: la de los Decretos-Leyes, cuya característica urgencia aconseja su exención de la

\footnotetext{
53 Arts. 6.1.d)-LCES y 45.1-ROFICES.

54 Art. 6.1.d)-LCES.

55 Art. 40.11-ROFICES.

56 Art. 7.1.1.a)-LCES.
} 
necesidad de dictamen, y la de las leyes de presupuesto, cuya exclusión viene expresamente prevista en el artículo 7.1.1.a) LCES.

La puesta en práctica del primero de los dos criterios citados ofrece, sin duda, dificultades. El propio Consejo, en su Dictamen $n$. $^{\circ}$ 4/1995 sobre el Proyecto de Real Decreto de desarrollo de la Ley 21/199157, hace referencia al problema que, en ocasiones, puede representar la determinación de lo que son materias socio-económicas y laborales y se inclina, precisamente, por aceptar la fórmula utilizada en dicho Proyecto para fijar el ámbito exacto de las citadas materias. Tal fórmula no es otra que hacer coincidir ese ámbito con la enumeración de materias ${ }^{58}$ que hace el artículo 7.1.3 de la Ley 21/1991 para determinar el objeto sobre el que deben versar los estudios o informes a realizar por el Consejo "en el marco de los intereses económicos y sociales que son propios de los interlocutores sociales». De esta forma, se produce una clara identificación entre el ámbito material propio de los Anteproyectos de Ley y Proyectos de Reales Decretos Legislativos sometidos al dictamen preceptivo del CES y el ámbito propio de los estudios o informes. Ahora bien, no habiendo Ilegado a aprobarse el citado Proyecto de Real Decreto, tal identificación entre los dos ámbitos materiales no ha podido ser llevada a efecto, por lo que sigue siendo el Gobierno quien - caso por caso - debe determinar cuando un concreto texto prenormativo incide en la materia socio-económica y laboral. Queda, pues, al arbitrio del Gobierno establecer si se ha producido el hecho básico lesto es, la incidencia en la referida materia) que motiva la remisión del texto al Consejo, con el evidente riesgo de "error" gubernamental en la valoración y el subsiguiente "olvido" de dicha remisión (como, de hecho, ya ha ocurrido). Para la solución de este problema podría propugnarse que, hasta tanto no se fijen legal o reglamentariamente los baremos objetivos para valorar si se produce tal incidencia en materia propia del CES, el Gobierno pueda servirse del criterio propugnado por el Proyecto y admitido como válido por el propio CES en su Dictamen antes aludido.

57 Vid. el fascículo correspondiente a este Dictamen, editado por el CES, pág. 4.

58 Estas materias son las siguientes: Economía; Fiscalidad; Relaciones Laborales, Empleo y Seguridad Social; Asuntos Sociales; Agricultura y Pesca; Educación y Cultura; Salud y Consumo; Medio Ambiente; Transporte y Comunicaciones; Industria y Energía; Vivienda; Desarrollo Regional; Mercado Único Europeo y Cooperación con el Desarrollo (art. 7.1.3-LCES). 
Por su parte, la aplicación del segundo de los mencionados criterios - el subjetivo - impone, en primer lugar, la exclusión de las proposiciones de ley y de los proyectos de ley autonómica, puesto que ambos tipos de iniciativa legislativa tienen un origen claramente extragubernamental; $v$, en segundo lugar, hace nacer la duda sobre la constitucionalidad ${ }^{59}$ de la norma que, de modo general, prescribe la emisión de dictámenes sobre los Proyectos de Reales Decretos legislativos. El origen de tal duda se halla en que, según advierte $P$. SÁNCHEZ DE VEGA ${ }^{60}$, en este supuesto el Gobierno ejercita la función legislativa de forma excepcional y por delegación expresa de las Cámaras, contando para ello con la debida autorización constitucional ${ }^{61}$. Dada la excepcionalidad de este ejercicio, los principios y criterios que han de regirlo deben ser determinados por la ley delegante ${ }^{62}$. Es por ello - termina afirmando el autor citado-que debe ser «el propio legislador que delega quien en cada caso determine el carácter preceptivo del dictamen del Consejo" 63 .

Un segundo problema se plantea en relación con los dictámenes sobre proyectos de Reales Decretos ${ }^{64}$. En este supuesto, que constituye una excepción a la general exclusión de las normas de rango reglamentario del ámbito de aplicación del dictamen preceptivo, la actividad consultiva del CES referida a estos proyectos no se origina, de modo obligado, cuando el contenido normativo de éstos afecta o interesa a materias socio-económicas y laborales. Aquí, a diferencia del supuesto anterior, el Gobierno decide el envío del proyecto al CES cuando considera que tiene "una especial transcendencia en la regulación de las indicadas materias" ${ }^{65}$. Se deja, pues, nuevamente a la discrecionalidad del Gobierno determinar si el texto prenormativo tiene esa "especial transcendencia» que motiva su remisión al Con-

59 GONZÁLEZ DE LA ALEJA se pronuncia abiertamente en contra de su constitucionalidad. Cfr. GonzÁLEZ DE LA ALEJA M., "Notas a propósito de la Ley 21/1991, por la que se crea el Consejo Económico y Social», Revista Jurídica de la Universidad de Castilla-La Mancha, n. 14 (abril, 1992), pág. 61.

60 SÁNCHEZ DE VEGA, "Primeras...", op. cit., pág. 182.

61 Art. 82.1-CE: "Las Cortes Generales podrán delegar en el Gobierno la potestad de dictar normas con rango de ley sobre materias determinadas no incluidas en el artículo anterior".

62 Según el artículo 82.4 de la Constitución Española, "las leyes de bases delimitarán con precisión el objeto y alcance de la delegación legislativa y los principios y criterios que han de seguirse en su ejercicion.

63 SÁNCHEZ DE VEGA, "Primeras...", op. cit., pág. 182.

64 Art. 7.1.1.a)-LCES.

65 Art. 7.1.1.a)-LCES. 
sejo, con los mismos e indudables riesgos que se advertían en el anterior supuesto.

El tercero y último de los problemas que cabe detectar en el ámbito que ahora consideramos se refiere a los dictámenes sobre anteproyectos de ley o proyectos de disposiciones administrativas que afecten a la organización, competencias o funcionamiento del CES ${ }^{66}$. El criterio de inclusión de este supuesto ha sido, evidentemente, el del interés del CES: cualquier normativa, sea de rango legal o reglamentario, que pueda afectarle debe también someterse a su dictamen ${ }^{67}$.

Respecto de los anteproyectos de ley, se plantea la cuestión de si la norma se está refiriendo sólo a anteproyectos que, en su integridad, afectan a los aspectos enunciados o si, por el contrario, también se aplica a las normas dispersas que, aun integradas en anteproyectos relativos a materias distintas de lo socio-económico $y$ laboral, pueden incidir en dichos aspectos. R. ESCUDERO se pronuncia a favor de este segundo planteamiento, bien entendido que sólo queda sometida a dictamen "la parte del anteproyecto relacionada con el Consejo" 68 .

En cuanto a los proyectos de disposiciones administrativas, cabe señalar que, al ser elaborados por órganos de la Administración Pública estatal distintos del CES, la potestad auto-organizativa de éste, a la que más adelante nos referiremos ${ }^{69}$, puede quedar -como previene G. MAESTRO - "desnaturalizada de hecho»70.

No hay, por el contrario, ningún tipo de problemas en relación con los dictámenes facultativos, a que se refiere el artículo 7.1.2 de la Ley 21/1991 cuando contempla la posibilidad de que el Gobierno de la Nación o cualquiera de sus miembros recaben el dictamen del Consejo, si lo consideran conveniente. El objeto de este tipo de dictámenes no

66 Art. 7.1.1.b)-LCES.

67 El mismo criterio se sigue por la Ley Orgánica 3/1980, de 22 de abril, del Consejo de Estado, cuyo artículo 21.6 señala como objeto de preceptiva consulta a los "anteproyectos de ley o proyectos de disposiciones administrativas, cualquiera que fuere su rango y objeto, que afecten a la organización, competencia o funcionamiento del Consejo de Estadon. Cabe observar, pues, una gran similitud entre ambas regulaciones, lo que nos permite aventurar que, en este punto como en algunos otros, el legislador del CES ha encontrado en la normativa del supremo órgano consultivo su más directa fuente de inspiración.

68 EsCUDERO, "El Consejo....», op. cit., pág. 83.

69 Vid. infra, epígrafe 5.1 de este artículo.

70 MAestro Buelga, "El momento...", op. cit., pág. 87. 
queda, en efecto, sujeto a los estrechos límites de un número determinado de supuestos, como ocurre en los preceptivos, sino que se amplía a cualquier asunto. No obstante, ha de sobreentenderse que el asunto debe versar sobre materia competencia del Consejo ${ }^{71}$.

\section{LA POSIBLE PERTURBACIÓN DE LA AUTONOMÍA DEL CES}

El último de los problemas que hemos podido detectar en el funcionamiento del CES, el de la posible perturbación de su autonomía, viene siendo puesto de manifesto por la doctrina científica desde los primeros momentos en que dicho ente consultivo comienza su andadura. Como se sabe, el Consejo goza, por consecuencia de su encuadramiento en la Administración Institucional del Estado, de una plena autonomía orgánica y funcional para el cumplimiento de sus fines. En este sentido se expresan, con claridad meridiana, no sólo la Exposición de Motivos de la Ley 21/1991 cuando se refiere a las líneas básicas informadoras de la misma, sino también el propio articulado (concretamente, el artículo 1.3 LCES). Ahora bien, la afirmación legal que acaba de exponerse necesita ser matizada, por cuanto hay ciertos elementos potencialmente perturbadores de esa autonomía que se predica, a saber: la potestad reglamentaria del Gobierno; la facultad de éste para nombrar y destituir al Presidente; y el vínculo de mandato imperativo entre los Consejeros y las organizaciones sociales que los designan. Tratemos de ellos por separado.

\subsection{El riesgo de colisión entre la potestad reglamentaria del Gobierno y la del CES}

Un primer factor de perturbación que debe afrontar el Consejo es el representado por la posible incidencia de la acción reglamentadora del Gobierno sobre el mismo ámbito objetivo en que aquél se halla facultado para ejercer su propia potestad reglamentaria. Debe significarse, en efecto, que, como una de las garantías de la independencia del CES, el artículo 7.1.4 de la Ley 21/1991 confiere al Consejo la función de "regular el régimen de organización y funcionamiento internos", función que debe enmarcarse, lógicamente, dentro de las genéricas directrices que, al respecto, se contienen en la citada Ley. Es

71 En este sentido, Escudero, "El Consejo...",op. cit., pág. 84. 
decir, se trata de una potestad reglamentaria para el desarrollo de las normas legales y referida a un ámbito normativo muy concreto: la regulación de la organización del CES y de su funcionamiento interno. De ahí que pueda calificarse como potestad reglamentaria de carácter "doméstico", que no agota la función normativa del Consejo, toda vez que el Pleno cuenta, a su vez, con la competencia necesaria para aprobar las directrices e instrucciones que, en desarrollo de la normativa reglamentaria, considere convenientes ${ }^{72}$.

El problema que se le plantea al CES en el ejercicio de su función normativa estriba en que debe respetar el desarrollo reglamentario sobre las mismas materias (organización y funcionamiento) que pueda hacer el Gobierno ${ }^{73}$ en uso de la facultad que, sin ningún tipo de límites, le reconoce la Disposición Final 2. ${ }^{a}$ de la Ley ${ }^{74}$. ¿Debe el Consejo estar condicionado por la regulación reglamentaria que, en desarrollo de las normas legales sobre organización y funcionamiento interno, dicte el Gobierno? La cuestión es polémica, pero lo más correcto parece una respuesta afirmativa ${ }^{75}$. De ser así, se corre el claro riesgo de que una abusiva actuación del Gobierno, en uso de la aludida autorización legal, pudiera llegar a vaciar de contenido la facultad de auto-organización del CES. Como afirma A. SANTANA, "una utilización extrema por parte del Ejecutivo de esta habilitación puede llevar a que los vacíos de regulación, que en principio estaban llamados a ser colmados mediante el reglamento interno [...], sean solucionados mediante meras disposiciones administrativas» ${ }^{76}$. En definitiva y según lo expresa G. MAESTRO, la potestad reglamentaria "doméstica» del Consejo puede quedar "desnaturalizada» en la práctica77, no quedan-

72 Art. 15.9-ROFICES.

73 Existe un Proyecto de Real Decreto de desarrollo de la Ley 21/1991, al que ya hemos venido haciendo referencia a lo largo del texto. Dicho Proyecto fue, incluso, dictaminado (Dictamen $n .^{\circ} 4 / 1995$ ) por el propio Consejo en su sesión plenaria de 19 de julio de 1995, pero no llegó a ser aprobado por el Gobierno del PSOE, a la sazón en el poder, ni por el del PP que le sucedió. Y no hay visos tampoco de que el actual Gobierno popular vaya a retomar el Proyecto o a sustituirlo por otro.

74 Esta Disposición Final autoriza al Gobierno, previa propuesta de los Ministros deTrabajo y Seguridad Social y de Economía y Hacienda, a dictar las normas necesarias para el desarrollo de la normativa legal. Al no existir ningún condicionante al respecto, parece claro que el desarrollo reglamentario también puede afectar a las normas legales sobre organización y funcionamiento.

75 En este sentido, Escudero, "El Consejo...», op. cit., pág. 92.

76 Santana Gómez, «El Consejo...», op. cit., pág. 29.

77 Maestro Buelga, «El momento...»,op. cit., pág. 87. 
do más solución al problema que la voluntaria auto-restricción del Ejecutivo en el ejercicio de sus competencias.

\subsection{La «conexión gubernamental» del Presidente del CES}

Un segundo factor de posible perturbación de la autonomía del CES viene constituido por el nombramiento y destitución del Presidente, que corresponden al Gobierno. Aunque para dicho nombramiento el Gobierno necesite el apoyo previo de dos tercios de los miembros del $\mathrm{CES}^{78}$, si lo que se quiere es garantizar la independencia parece mucho más conveniente una elección interna de entre todos sus miembros (como ocurre con los vicepresidentes), más aún cuando el Gobierno no tiene representación formal alguna en el Consejo. Y con la destitución del Presidente el tema es todavía más grave, por cuanto para acordarla el Gobierno no necesita más que el dictamen preceptivo, pero no vinculante, emitido por el Pleno del CES ${ }^{79}$. Esta incomprensible falta de simetría entre nombramiento y destitución hace patente - en expresión de A. SANTANA ${ }^{80}$ - "la conexión gubernamental del Presidente", lo que, en buena lógica, choca con la pretensión de independencia.

\subsection{Posibles limitaciones a la actuación individual de los Consejeros}

Por último, según observa R. ESCUDERO ${ }^{81}$ respecto de la autonomía e independencia en la actuación individual de los miembros del Consejo, consagrada en el artículo 2.6 de la Ley 21/1991, el alcance de dicha esfera autónoma puede quedar limitado en gran medida por la posibilidad que, a tenor de lo dispuesto en el artículo 3.5.c) de la Ley, tienen las organizaciones sociales de cesar en cualquier momento a los Consejeros designados. Tal posibilidad parece dejar bien clara, en opinión de S. DE VEGA ${ }^{82}$, la existencia de una relación de mandato imperativo entre el Consejero y la organización que lo designa, relación que, sin duda, condiciona o determina, en gran medida, el ámbi-

\footnotetext{
78 Vid. arts. 3.1-LCES y 23.1-ROFICES.

79 Vid. arts. 3.5.a) Y 7.1.1.a)-LCES.

80 Santana Gómez, "El Consejo...", op. cit., pág. 26.

81 ESCUDERo, "El Consejo...", op. cit., pág. 72.

82 SÁNCHEz dE VEGA, «Primeras...», op. cit., pág. 176.
} 
to autónomo de actuación del Consejero, ya que éste, aunque la Ley no lo reconozca de modo expreso, se encuentra sometido, de hecho, a las directrices emanadas de la organización que lo designa. Y ello porque, como reconoce J. L. GARCÍA RUIZ (que niega, por cierto, la existencia del referido mandato imperativol, "cuesta trabajo sostener la hipótesis del mantenimiento de un Consejero que sistemáticamente actúe en desacuerdo con la organización que lo designó o propuso „83, cuando ésta puede optar, sin limitación alguna, por destituirlo en el momento que considere conveniente.

83 García Rulz, El Consejo..., op. cit., pág. 109, nota n. 214. 